\title{
EVALUATION OF THE QUALITY OF LIFE PEOPLE INFECTED WITH HCV - PROPOSED RESEARCH INSTRUMENTS
}

\author{
OCENA JAKOŚCI ŻYCIA OSÓB ZAKAŻONYCH WIRUSEM HCV \\ - PROPONOWANE NARZĘDZIA BADAWCZE
}

Military Clinical Hospital No. 1 with Polyclinic, Independent Public Health Unit, Lublin

S u m m a r y

I n t r o d u c t i o n. HCV is an important medical and social problem in Poland and worldwide.

$\mathrm{O} \mathrm{b} \mathrm{j} \mathrm{e} \mathrm{c} \mathrm{t} \mathrm{i} \mathrm{ve.} \mathrm{Presentation} \mathrm{of} \mathrm{the} \mathrm{instruments} \mathrm{for}$ investigating quality of life of patients diagnosed with hepatitis $\mathrm{C}$.

R e s u 1 t s: The World Health Organization Quality Life Assessment Questionnaire (WHOQOL) evaluates the dimensions of the quality of life: physical, psychological, spiritual, independence, social relations, and the patient's environment. The WHOQOL-Bref questionnaire assesses the quality of a patient's life within four spheres: physical, psychological, social and environmental. The following questionnaires may also be used: the Hepatitis Quality of Life Questionnaire (HQLQv2), the Chronic Liver Disease Questionnaire (CLDQ), and the Chronic Liver Disease Questionnaire - Hepatitis C (CLDQ-HCV). For the assessment of coping with the disease, the KMORSZCH scale may be applied (Brief Method of Assessment of Coping with Disease). The Nottingham Health Profile (NHP) allows the evaluation of patient's functioning in daily life. The Health Behaviour Inventory (IZZ) may be an instrument for evaluation of the level of health behaviours. For assessment of health dimensions in the bio-psych-social sphere the List of Health Criteria (LKZ) may be used. Expectations of patients infected with HCV from a general practitioner may be assessed by the Patient Request Form (PRF). The Satisfaction With Life Scale (SWLS) allows the assessment of the level of satisfaction with life. The degree of acceptance of the disease may be evaluated by the Acceptance of Illness Scale (AIS), whereas the sense of health control may be evaluated by the Multidimensional Health Locus of Control (MHLC).

$\mathrm{C}$ o $\mathrm{n} \mathrm{cl} \mathrm{u} \mathrm{s} \mathrm{i} \mathrm{o} \mathrm{n}$ s. The presented instruments for evaluation of the quality of life of patients with hepatitis $\mathrm{C}$ will enable researchers the recognition of specific aspects of functioning of these patients in the bio-psycho-social sphere.

\section{Streszczenie}

$\mathrm{W}$ s $\mathrm{t}$ ę $\mathrm{p}$. Wirusowe zapalenie wątroby typu $\mathrm{C}$ jest istotnym problemem medycznym i społecznym w kraju i na świecie.

C e 1 p r a c y. Przedstawienie narzędzi do badania jakości życia osób z rozpoznanym wirusowym zapaleniem wątroby typu C.

$\mathrm{W}$ y $\mathrm{n} \mathrm{i} \mathrm{k}$ i: Kwestionariusz ankiety WHOQOL (The Word Heath Organizationn Quality Life Assesment) pozwala ocenić wymiary jakości życia: fizyczny, psychologiczny, duchowy, niezależność, relacje społeczne, środowisko chorego. Kwestionariuszem WHOQOL-Bref można ocenić jakość życia chorego w zakresie czterech dziedzin: fizycznej, psychologicznej, społecznej i środowiskowej. Narzędziem do oceny jakości życia chorych z wirusowym zapaleniem wątroby jest kwestionariusz HQLQv2 (Hepatitis Quality of Life Questionnaire). Do oceny jakości życia chorych z przewlekłą chorobą wątroby może posłużyć kwestionariusz CLDQ (Chronic Liver Disease Questionnaire). Natomiast do oceny jakości życia pacjentów z przewlekłą chorobą wątroby z powodu WZW typu C można wykorzystać kwestionariusz CLDQ-HCV (Chronic Liver Disease Questionnaire Hepatitis $\mathrm{C}$ ). Do oceny radzenia sobie $\mathrm{z}$ chorobą może 
posłużyć skala KMORSZCH (Krótka Metoda Oceny Radzenia Sobie z Choroba). Kwestionariusz NHP (The Nottingham Health Profile) pozwala na ocenę funkcjonowania chorego w życiu codziennym. Narzędziem oceny poziomu zachowań zdrowotnych może być kwestionariusz IZZ (Inwentarz Zachowań Zdrowotnych). Do oceny wymiarów zdrowia w sferze bio-psycho-społecznej można zastosować kwestionariusz LKZ (Listę Kryteriów Zdrowia). Oczekiwania zakażonych wirusem HCV wobec lekarza ogólnego można ocenić skalą PRF(Patient Reguest Form). Skala SWLS (Satisfaction With Life Scale) pozwala

ocenić poziom satysfakcji z życia. Do określenia stopnia akceptacji choroby można wykorzystać skalę AIS (Acceptance of Illness Scale). Do oceny poczucia kontroli zdrowia może posłużyć wielowymiarowa skala MHLC (Multidimensional Health Locus of Control).

W n i o s k i. Zaprezentowane narzędzia do oceny jakości życia osób z rozpoznanym wirusowym zalaniem wątroby typu C umożliwią badaczom poznanie specyficznych aspektów funkcjonowania tych chorych w sferze bio-pychospołecznej.

Key words: quality of life, medical and social problems, HCV

Stowa kluczowe: jakość życia, problemy medyczne i społeczne, WZW typu C

\section{INTRODUCTION}

Several-year observation of the epidemiological situation in Poland shows that hepatitis $\mathrm{C}$ is a serious medical and social problem among Polish children and adults. The etiologic factor of hepatitis $\mathrm{C}$ is hepatitis $\mathrm{C}$ virus $(\mathrm{HCV})$. HCV infection is transmitted by blood, proliferates mainly in the liver, as well as in other organs, i.e. spleen, pancreas, adrenal glands, brain, bone marrow, thyroid gland, lymph nodes, and peripheral blood mononuclear cells [1].

Estimation data show that in 2005 in Poland approximately 600,000 people were infected with HCV, while in 2013 - about 730,000 [2]. The majority of hepatitis C cases in Poland (approx.80\%) are related with medical procedures performed in health care facilities.

About 3,000 new cases occur annually. Since the detection of the virus, evaluation of the prevalence of hepatitis $\mathrm{C}$ has been a problem in practically all societies [3]. The epidemiological data published are incomplete and underestimated. At least $50 \%$ of those infected are unaware of the ongoing pathological process, which often takes an asymptomatic or mildly symptomatic course. In many patients, the medical diagnosis concerns late consequences of hepatitis C cirrhosis or liver cancer. The disease also causes disorders in the somatic, psychological and social spheres. Improvement of the quality of life of patients is an important aspect of nursing and medical care, and providing assistance in solving important physical, psychological and social problems.

\section{RESULTS}

The World Health Organization Quality Life Assessment (WHOQOL) assesses the dimensions of the quality of life: physical, psychological, spiritual, independence, social relations and patient's environment [4].

Literature review demonstrates that the instruments, scales for evaluating the quality of life of patients with a chronic disease are being constantly improved. An example is the short version of the WHOQOL questionnaire - WHOQOL-Bref, consisting of 26 items, and enables evaluation of the quality of a respondent's life within the last 2 weeks, in four domains: physical, psychological, social and environmental. This instrument also contains 2 questions concerning: 1) the general perception of the quality of life, 2) the general perception of own health. The respondents provide an answer by ascribing a numerical value on a 5-point scale - within the range maximally positive - maximally negative [5]. The higher the number of scores, the better the quality of life [6].

The quality of life of patients with hepatitis $\mathrm{C}$ is evaluated by the Hepatitis Quality of Life Questionnaire (HQLQv2) which is in two parts: 1) assesses functional efficacy, 2) evaluates the wellbeing of the patients. The first section contains 36 items of the Short Form General Health Survey (SF$36 \mathrm{v} 2$ ), which evaluate the quality of life from the aspects of physical and psychological functioning, experienced pain, general state of health, possessed energy, social functioning and mental health $[7,8]$. The second section includes 15 items assessing the degree of health risk, the patient's general wellbeing, functional limitations related with the inflammatory process in the liver, or specific life risk.

Quality of life of patients with chronic diseases of the liver is investigated using the Chronic Liver Disease Questionnaire (CLDQ), irrespective of etiology and degree of advancement of pathological changes. The questionnaire contains 29 items divided into 6 groups concerning: the feeling of fatigue, life 
activity, emotional responses, abdominal complaints, general symptoms, and nervousness [9]. Another instrument is the Chronic Liver Disease Questionnaire - Hepatitis C (C systemic symptoms, and activity/energy. The level of the quality of life of patients infected with $\mathrm{HCV}$ virus is calculated based on the mean value from all scores in individual domains (CLDQ - HCV) - so-called global score - the higher the score the better the quality of life [10].

While evaluating coping with the disease by patients infected with $\mathrm{HCV}$ virus, the Brief Method of Assessment of Coping with Disease (KMORSZCH) may be applied. The KMORSZCH scale allows the distinguishing of four styles of coping with stress often caused by the disease: style focused on avoidance, style concentrated on emotions, style focused on the task, and style concentrated on seeking the best solutions. The KMORSZCH scale is a simple instrument with relatively good psychometric properties, which is possible to apply during a medical appointment [11].

Problems associated with health, and their effect on daily living of patients infected with HCV virus within the scope of physical, social functioning, and social contacts may be investigated using the Nottingham Health Profile (NHP) questionnaire. This instrument was used in many European countries. The first part of the NHP scale contains 38 items divided into 6 categories: sleep, energy, emotional reactions, social isolation, physical efficacy, and pain. The second part of the NHP questionnaire contains 7 questions pertaining to the health-related problems within the scope of: work, activity outside home, social life, relations with household members, sex life, hobby, and spending leisure time. Use of the NHP scale conditions the evaluation of poor functioning of a patient in the indicated areas; however, it does not include the patient's wellbeing. A patient may be ascribed maximum 100 scores, and a high number of scores evidences serious health problems [12, 13, 14].

The level of health behaviours in patients infected with $\mathrm{HCV}$ virus may be investigated using the Health Behaviours Inventory (IZZ) - designed by Prof. Zygfryd Juczyński. The IZZ questionnaire contains 24 statements describing health-related behaviours and allows assessment of psychosocial variables, i.e. the general intensity of health promoting behaviours, and degree of intensity of four categories of health behaviours: adequate nutritional habits, prophylactic behaviours, and positive psychological attitude.
The dimensions of health among patients infected with $\mathrm{HCV}$ virus in the bio-psycho-social sphere may be assessed by the List of Health Criteria (LKZ), which contains 24 statements describing positive elements of various dimensions of physical, psychological and social health. Respondents mark their preferences by indicating the statements important for them in the evaluation of health. The selected statements must be ordered from the most serious to the least important [15].

For evaluating the expectations of a patient from a doctor, the Patient Request Form is applied, the socalled PRF scale developed by P. Salmon and J. Qiune, adopted by Z. Juczyński. The PRF scale is completed by a patient shortly before contact with a general practitioner. The instrument consists of 18 statements concerning various reasons for a patient reporting to a general practitioner. These statements concern the explanation of the disease, seeking support, and obtaining information concerning examinations and treatment [15].

The level of satisfaction with life of patients infected with HCV virus may be investigated by means of the Satisfaction With Life Scale (SWLS), developed by E. Diener, R.A. Emmons, R.J. Larson, and S. Griffin in 1985 (Polish adaptation by Prof. Zygfryd Juczyński). The scale contains 5 statements evaluated on a 7-degree scale. The respondents evaluate to what degree each of these statements refers to their lives todate. The result gives a general indication of the feeling of satisfaction with own life. The scope of results falls within the range from 5 - 35 scores. The higher the scores, the greater the feeling of satisfaction with life [16]

The degree of acceptance of the disease and its effect on the functioning of patients with by hepatitis $\mathrm{C}$ is determined by the Acceptance of Illness Scale (AIS), constructed by B. J. Felton et al. from the Center for Community Research and Action, Department of Psychology, New York University (Polish adaptation by Prof. Zygfryd Juczyński). The scale contains 8 statements describing the negative consequences of poor state of health. These consequences come down to the acceptance of limitations imposed by the disease, lack of self-sufficiency, sense of being dependent from others, and low self-esteem. All the statements express specified difficulties and limitations resulting from the disease. A definite consent expresses poor adaptation to the disease, whereas a definite lack of consent means acceptance of the disease. The sum of all scores 
is the general measure of the degree of acceptance of the disease, within the range from 8 - 40 scores. A low result means lack of acceptance and adaptation to the disease, and a strong feeling of psychological discomfort. A high result evidences the acceptance of own pathological condition, manifested by the lack of negative emotions related with the occurrence of the disease [15].

The Polish version of the Multidimensional Health Locus of Control (MHLC) by Kenneth A. Wallston, Barbara S. Wallston, and Robert de Vellis, is used for investigating the beliefs of an individual concerning three types of health control, i.e. internal (control of own health depends on oneself), effect of others (state of own health is affected by others, mainly medical staff), and coincidence (state of health depends on coincidence or other external factors). In each of the MHLC scales, 6 - 36 scores may be obtained. The higher the result, the stronger the belief that a given factor exerts an effect on the patient's state of health [16].

\section{CONCLUSIONS}

1. The quality of life of patients infected with HCV virus should be evaluated from perspective.

2. The presented review of instruments will allow researchers to select the proper questionnaire for evaluation of the quality of life in the bio-psychosocial sphere of patients infected with HCV virus.

\section{REFERENCES}

1. Kamińska A, Bednarska A, Radkowski M. Extrahepatic replication of hepatitis C virus (HCV). Przegl. Epidemiol. 2003; 57, 317-322.

2. Sierpińska L. Hepatitis $\mathrm{C}$ as a health problem in Poland. Jacobs Journal of Nursing and Care 2015; 1(1), 1-5.

3. www.pzh.gov.pl/.../28\%20lipca_dzień\%20Wirusowych \%20zapaleń\%20-access 11.04. 2014.

4. Wołowicka L, Jaracz K. Polish version of the WHOQOL - WHOQOL 100 and WHOQOL-BREF. [In:] Wołowicka L (ed.). Quality of life in medical sciences. Karol Marcinkowski Medical University. Poznań 2001.

5. Grochans E, Syta D, Szkup -Jabłońska M, Jurczak A, Wieder -Huszla S, Grzywacz A, Rotter I, Karakiewicz B. Evaluation of quality of life of patients with chronic hepatitis C. Problemy Pielęgniarstwa 2011; 19(2), 171-176.
6. Jaracz K, Kalfoss M. Górna K. (et al). Quality of life in Polish respondents: psychometric properties of the Polish WHOQOL - Bref. Scand. J. Car. Sci. 2006; 20(3), 251260.

7. Ware JE, Kosiński M, Dewey JE. How to score Version 2 of the SF-36 Health Survey. Lincoln, RI. QualityMetric Incorporated 2000.

8. Żołnierczyk-Zreda D, Wrześniewski K, Bugajska J, Jędryka-Góral A. Polish version of the SF-36v2 questionnaire for studies of the quality of life. CIOP-PIB. Warsaw 2009.

9. Pui Lam ET, Kuen Lam CL, Lai Lung C (et al). Psychometrics of the chronic liver disease questionnaire for Southern Chinese patients with chronic hepatitis B virus infection. World J Gastroenterol 2009; 15, 32883297.

10. https://clinicaltrials.gov/ct2/show/NCT00863109 - access 05.06.2015.

11. Kokoszka A, Jodko A, Radzio R. Short method of evaluation of coping with disease: genesis and description of the draft version of the method. Przewodnik Lekarza 2003; 10, 39-46.

12. Hunt SM. Measuring health in clinical care and clinical trials. In: Measuring health: a practical approach. Telling Smith G (ed.). John \& Sons. Chichester 1986.

13. Majkowicz M, Chojnacka-Szawłowska G. Methodological problems of studies of the quality of life [In:] de Walden-Gałuszko K, Majkowicz M. Quality of life in cancerous disease. Wyd. Uniwersytetu Gdańskiego. Gdańsk 1994.

14. Wrześniewski K. Study of self-reported state of health by means of Polish adaptation of the Nottingham Health Profile. W: Karski J, Kirschner H, Leowski J. (ed.). Contemporary needs and possibilities of measurement of health. Ignis. Warsaw 1997.

15. Juczyński Z. Measurement instruments in health promotion and psychology. Laboratory for Psychological Tests. Warsaw 2001.

16. Juczyński Z. Measurement instruments in health psychology. Przegląd Psychologiczny 1999; 42(4), 4356.

\section{Address for correspondence:}

\section{Lidia Sierpińska}

Military Clinical Hospital No.1 with Polyclinic, Independent Public Health Unit,

Al. Racławickie 23, 20-049 Lublin

Tel. +48 2611832 97; 507810339

Fax: +48 2611832 77;

e-mail: sierpinska1@wp.pl

Received: 12.05.2015

Accepted for publication: 10.11.2015 